\title{
Copying Urban Identity and Pasting it on Residential Architecture: 'Themes' For Gated Settlements in İstanbul
}

\author{
Kentsel Kimliği Kopyalamak ve Konut Mimarisine Yapıştırmak: \\ istanbul'da Kapalı Konut Yerleşimleri Için "Tema"lar
}

\section{S. Banu GARIP, ${ }^{1}$ Ervin GARIP²}

\section{ABSTRACT}

The aim of the present study was to discuss an emerging trend in istanbul housing -a trend of essentially copying urban identity and pasting it on housing- in an effort to test the reaction of potential users to these environments. The present study includes research regarding a possible divergence in opinion of these environments among laypeople and experts in the field of architecture. Sample sites selected were themed "San Marco Square, Venice" and "Bosphorus, İstanbul." It was hypothesized that a difference in opinion would be present among groups regarding the description of and preferences for visual attributes of the sample sites. Twenty architects and 20 non-architects were asked to describe the selected buildings. A "Visual Evaluation Test" featuring images of the buildings was included in the questionnaire. Significant differences in opinion were present among the groups of respondents. Architects generally held a negative view of the sites, focusing primarily on design and context. Non-architects evaluated the visual attributes positively, focusing primarily on "function-units" and quality. They were uninterested in Venice or the Bosphorus as housing concepts, but were largely impressed by the newness of the sites, their social and recreational facilities, and their planned organization, features consumers are deprived of within the city center.

Keywords: Gated housing; globalization; identity; imitation; residential architecture; visual consumption.

\section{Öz}

Çalışma, istanbul'da konut çevrelerinde son birkaç yıl içinde gözlemlenen ve farklı kentsel kimlikleri kopyalayarak birebir uygulayan yeni bir eğilimin tartşsılmasını ve söz konusu konut yerleşimlerine potansiyel kullanıcıların verdikleri tepkileri anlamayı amaçlamaktadır. Bu çerçevede bir araştırma yapılmış ve "Venedik San Marco Meydanı" ve "istanbul Boğazı"nı kopyalayarak bu mekanlarda yaşamayı vaadeden iki farklı konut yerleşimi seçilmişitir. Seçilen konut yerleşimleri ile ilgili "mimar" ve "mimar olmayan" potansiyel kullanıcıların değerlendirmeleri ve tercihlerini analiz eden bir çalışma gerçekleştirilmiştir. Çalışma, iki farklı grubun yerleşimlerin görsel özelliklerini tanım ve tercihlerinde farklılıklar olacağı hipotezini de test etmektedir. Yirmi mimar ve 20 mimar olmayan katılımaya, konut yerleşimlerini değerlendirmeleri için bir "görsel değerlendirme testi" uygulanmıştır. Anket uygulaması ile gerçekleştirilen değerlendirme testinde seçilen konut yerleşimlerinin imajları kullanılmıştır. Sonuçlar, iki grup arasında önemli farklılıklar olduğunu göstermektedr. Mimarlar, konut yerleşimlerinin değerlendirilmesinde genel olarak negatif bir eğilimdeydi ve çoğunlukla "tasarım ve bağlam" üzerine odaklanmıştır. Mimar olmayanlar ise konut yerleşimlerinin özelliklerini genel olarak olumlu olarak değerlendirmiş ve "fonksiyon-birimler" ve "kalite" konuları ile ilgilenmişlerdir. Mimar olmayanların, kentsel kimliklerin kopyalanmasının en önemli amacı olarak görünen "Venedik'te yaşamak" veya "Boğaz'da yaşamak" konseptleri ile ilgilenmedikleri, onları daha çok yerleşimlerin "yeni, planlanmış ve düzenli" olmalarının, sosyal ve rekreasyonel alanları gibi kent merkezinde yoksun kaldıkları özelliklerin cezbettiği anlaşılmaktadır.

Anahtar sözcükler: Kapalı konut yerleşimleri; küreselleşme; kimlik; taklit; konut mimarisi; görsel tüketim.

'Department of Interior Architecture, Istanbul Technical University Faculty of Architecture, Istanbul, Turkey ${ }^{2}$ Department of Interior Architecture and Environmental Design, Istanbul Kultur University Faculty of Art and Design, Istanbul, Turkey. 


\section{Introduction}

In today's globalized world, distances can be traveled in shorter amounts of time, and the relationship between humans, place and time have been redefined because of developments in technology, along with the improvement of transport and communication systems. The number of travels to different parts of the world has increased, and movement between locations takes place rapidly as travelers seek to discover new places, cultures and lives. Besides all of these, owing to virtual networks and developing technology, people are getting capable of accessing to any information and images of any place around the world excessively. We live in an era that is characterized by a perpetual flow of information and images. Increase in the accessibility to information physically or virtually is getting to affect people's pleasures, tastes, priorities, needs and preferences.

The image of a region, an area, or even a city is a complex amalgam of its people, the ethnic mix that is contributing to or has contributed to its character, its architecture, its overall aesthetic appeal, its climate and its industry (Fisher, 1994). It is usually thought of in terms of the purely visual and fixed picture, but a characteristic quality of the senses is their tendency to mingle and integrate; a visual image is always accompanied with repercussions connotating experiences in other sense modalities (Pallasmaa, 2011). People go visit the Eiffel Tower in Paris, see Times Square or Central Park in New York, go to Topkapi Palace and the Bosporus in Istanbul or take gondola ride in Venice in Italy. And mostly people dream about living in such places since they have decent meanings in their minds. The study presented in this paper mainly focuses on a new trend in residential environments in Istanbul that essentially reflects this phenomenon to the way of marketing and architecture. The defined trend is offering a dream-life in an environment that is consist of copied images and artificial identities. Such places which are defined as "theme environments" in the literature offer users a fantastic world of dreams and entertainment within an idealized environment. The theme is primarily communicated though visual and vocal statements, as well as other senses like scent and touching (Milman, 2010). Issue of "theme environments" is discussed typologically through "theme parks" and "theme hotels" in literature, and by the emergence of the defined housing trends, a new discussion is critical for residential environments in Istanbul.

To look at the larger environmental context in Istanbul, great number of residential settlements have been in a rapid construction process particularly since the beginning of 1980s which can be defined as "gated settlements" (Garip and Sener, 2012). The number of new housing settlements is increasing and they are represented as "new life styles" to the citizens. Construction companies mostly tend to present a qualified life style in different ways and, besides, most of them also search for different strategies to compute with other companies and to attract potential customers. Recently, by offering "themes" for residential environments, image and identity of an ideal place to live in is copied and represented to the users artificially.

This research examines these practices, looking specifically at two samples of the identified gated housing settlements and focuses on how potential users react to these environments to discuss "how copying urban identity can lead to the creation of commodified images of place in residential environments".

\section{Copying the Urban Identity and Theme Environments}

"Copying" in the field of architecture has been discussed throughout time, and today, copying is quite common in applied structural environments, architectural projects and discourse as it is in the other fields. Aslan et.al. (2012) notes that there are many types of referential interpretation that are classified hierarchically as "imitation", "bricolage", "analogy", "interpretation", and "mimesis". Although there are no certain distinctions between these terms, "imitation" can be considered the term closest in meaning to copying. Discussions on the term "mimesis", which is fairly different from imitation, are traced back to ancient times in aesthetics history. Plato explored the idea of mimetic art in a theoretically extensive and probing manner, discussing themes and issues that had been voiced in various, but unsystematic ways in earlier Greek poetry and thought (Halliwell, 2002). According to the Plato's manifest The Republic, which introduced the term into literary theory over two thousand years ago, art "merely" imitates something real (Potolsky, 2006). Plato argues that art is an illusion and needs to be distinguished from truth and nature. The word " $\mathrm{mi}$ mesis" originally referred to the physical act of miming or mimicking something (Potolsky, 2006). According to Melberg (1995), mimesis is always the meeting-place of two opposing but connected ways of thinking, acting and making: similarity and difference. Gebauer and Wulf (1995) note that a spectrum of meanings of mimesis has unfolded over the course of its historical developement, including the act of resembling, of presenting the self, and expression as well as mimicry, 
imitatio, representation, and nonsensuous similarity. The accent may lie on similarity in sensuous terms, on a nonsensuous correspondence, or on an intentional construction of correlation (Gebauer and Wulf, 1995).

Aslan et al. (2012) define imitation, the term which has the closest meaning to "copying" in architecture as "a copy that totally or partially resembles an archetype that has been previously experienced and state that there is no inspiration from a direct copy and paste action". According to Rybczynski (2005), for most of the last 500 years, imitation was the sincerest form of architectural flattery; this pattern was established during the Renaissance when architects were trying to re-create the buildings of ancient Rome. Imitation architecture of today is similar. In the late 1960s, when architects were looking beyond modernism, Venturi began to look at architecture as a language of signs and symbols, looking at Las Vegas as a case study. In the 1960s, Venturi and Brown discussed the existence of an architectural communication. They suggest that communication gets ahead of space and that architecture transform into the symbol in the space (Rybczynski, 2005). The gigantic Jerde or Disney-style resorts, like blockbuster summer movies, must not only merge resorts with theme parks, but also generate an enormous enclosure that simulates a world or a microclimate in Las Vegas (Easterling, 2005).

Many hotels in Las Vegas now support a theme, such as ancient Egypt at the Luxor Hotel, the city and culture of Venice at the Venetian Hotel, ancient Rome at the Caesar's Palace Hotel, and natural wonders of the world at the Mirage Hotel, among others (Firat and Ulusoy, 2011). Every building of the Caesar's Palace Hotel in Las Vegas is an imitation of a historical building or environment; The Coliseum in Rome was imitated in the Plaza Building of the hotel, Neptunes Bar is another part of the hotel that looks like historical Roman and Greek architecture (Aslan et.al., 2012). Like many of the newest hotels on the Strip -Paris, the Venetian, the Bellagio, and Mandalay Bay- the management's ability to simulate famous forms of architecture and their environments, often at great expense, renders all forms of "real" travel superfluous; tourists need no longer be aliens in culturally "other" environments (Cass, 2004).

Symbols or images are increasingly consumed along with copied identities in theme environments. In fact, people become so accustomed to dealing with simulations that they begin to lose a sense of the distinction between the original and the simulation, the authentic and the inauthentic (Ritzer and Stillman,
2001). According to Ritzer and Stillman (2001), a postmodern world is characterized by the disappearance of originals and the increasing preeminence of inauthentic copies. Urry (1999) suggests that postmodernity involves three series of processes: visualization of culture, the collapse of permanent identities, and the transformation of time. Identities are the source of meaning (Castells, 2004), and meanings are tied to environment as information.

\section{Searching for "Themes" for Gated Housing}

\section{Settlements in Istanbul}

The phenomenon of people visiting, enjoying and appreciating themed environments, recognized by many astute observers of contemporary culture, has resulted in a respectable body of literature (Firat and Ulusoy, 2011). Milman (2010) notes that in today's theme parks and attractions, hotels, restaurants and other recreation, and tourist facilities, theming is reflected through architecture, landscaping, costumed personnel, rides, shows, food services, merchandising, and any other services that impact the guest experience.

Firat and Ulusoy (2011) define themed environments as spaces that are patterned to symbolize experiences and/or senses from a special or a specific past, present, or future place or event as currently imagined. Theme environments offer visitors a fantastic world of dreams and entertainment. Issue of "theme environments" is discussed typologically through "theme parks" and "theme hotels" in literature, and by the emergence of the defined housing trends, a new discussion is critical for residential environments in Istanbul. Akkaya and Usman (2011) define the theme hotels as "non-place" due to their contradictory relationship with time and history (Akkaya and Usman, 2011). Stating that these hotels should be defined as "fictional spaces", Akkaya and Usman (2011) suggest that what are consumed are actually the concepts of history, time and locality. As long as tourism is based on the emotion of satisfaction, theme spaces will be continuously designed.

In Istanbul, as a new trend, it can be observed that there is an effort on representing the residential settlements together with "themes" which are emposed to their architectural design. The themes offer to live in an ideal artificially created environment and an ideal life style. "Agean architecture" and "Agean life" in Istanbul; "to live in San Marco, Venice but in Istanbul"; "to own a waterside house next to a copied Bosphorus" can be defined as the starting point of a new approach in housing with themes, following the concept of "theme hotels" in Turkey. 


\section{Method}

Hubbard (1996) states that environmental meanings are constructed through codes or "knowledge structures" that are socially transmitted and based on learning and culture. In the literature, the differences in knowledge structures have been studied via comparing experts-nonexperts (Hubbard, 1996; Sanoff, 2006a) and students that are in different stages of architectural education (Wilson, 1996; Erdogan et.al, 2010). It is believed that, depending on the subjects' level of learning, the meaning given to architectural appearances can differ (Erdogan et.al, 2010). Architects as design professionals and non-architects are supposed to hold different codes through which they understand and evaluate the environment due to the differences in their system of knowledge structures that they attained within their educational processes and experiences. The study presented in this paper essentially aims to search the attitudes of potential users of the residential settlements that are represented with different themes while executing the differences and similarities between their evaluations and preferences.

A case study was conducted to determine how the potential users evaluate the defined housing settlements and how they perceive them. Two experimental groups were selected from architecture professionals and non-architects living in the city of Istanbul. Within the scope of the study, it is hypothesised that there would be a difference between the two groups' responses.

In this research, data was collected through a questionnaire given to 40 respondents and analysed. A "Visual Evaluation Test", which included images of the selected buildings was used within the questionnaire. The questionnaire used mixed questions including "multiple-choice questions" related with the "demographic characteristics"; "5-scale agree-disagree questions" about attitudes, and "open-ended questions" to gather subjective data.

Two different techiques were used to understand if there were some differences and similarities between the evaluations of the two groups. Firstly ratings of the participants which represent their attitudes were superposed graphically. Graphics were used to present the data for the scales, which were measured through a 5-point rating scale. Additionally, the participants were asked open ended questions. These analyses gave subjective information about the characteristics of each setting.

\section{Case Selection}

The case study was carried out for two housing settlements in Istanbul. One of the sample site is "Viaport Venezia" (Site1) which offers its residents to live in a housing settlement located in 'GaziosmanpaşaIstanbul' and at the same time to live in city of Venice, Italy. Within the settlement, in order to make a sense of experiencing "the other" space, dominant architectural components that form the identity of Piazza San Marco were used as images and symbols that copied and pasted to the architectural space.

Other sample site is "Bosphorus City" Housing Settlement which is located in 'Küçükçekmece-Istanbul' (Site2); an alternative generated artificial Bosphorus within the city of Istanbul copying its characteristic landscape and architecture specialized by the waterside houses.

\section{Survey Instrument}

A questionnaire was designed to understand the respondents' visual preferences and evaluations. A "Visual Evaluation Test", which included images was used within the questionnaire. A similar photographic approach was used by Sanoff (2006b) so as to compare the visual characteristics of a residential environment. Parallel research was done by Erdogan et.al. (2010) which used visual evaluation test in order to identify both differences and commonalities in the way first year architecture students-as freshmen- and fourth year architecture students-as pre-architects- perceive the discipline of architecture.

The questionnaire used mixed questions including "multiple-choice questions" related to the "demographic characteristics"; "5-scale agree-disagree questions about attitudes", and "open-ended questions" to gather subjective data. The respondents' attitudes toward the housing settlements were investigated through six questions which were asked for each site (Table 1).

Table 1.5-Scale agree-disagree questions asked for each site

The site looks like Venice/Bosphorus

The site is the same with Venice/Bosphorus

I would feel myself as if I live in Venice/Bosphorus in this site

To live in this site would make me happy

I would like to live in this site

I would purchase one of the houses if I could afford 
Table 2. Demographic characteristic of the respondents

\begin{tabular}{lll}
\hline \multicolumn{2}{l}{ Demographic characteristics } & \\
Age & 37 (between 20-40) & 2 (between 41-60) \\
Gender & 27 (female) & 13 (male) \\
Marital status & 20 (married) & 20 (single) \\
Education & 11 (undergraduate) & 29 (graduate-postgraduate) \\
Profession & 20 (architect-designer) & 20 (other) \\
Total & 40 &
\end{tabular}

Open-ended questions were asked to understand "the best-liked" and "the least-liked" features of the residential environments. The answers were categorized and grouped into four major categories. Although open-ended questions are not easy to evaluate and give subjective information, they are very helpful for obtaining different words that can be used to describe the physical environments (Sanoff, 1977; Sanoff, 1991). In this study, this technique helped to understand which words were mainly used to (1) describe the settings and (2) find out what the environmental cues were that affected how the par-

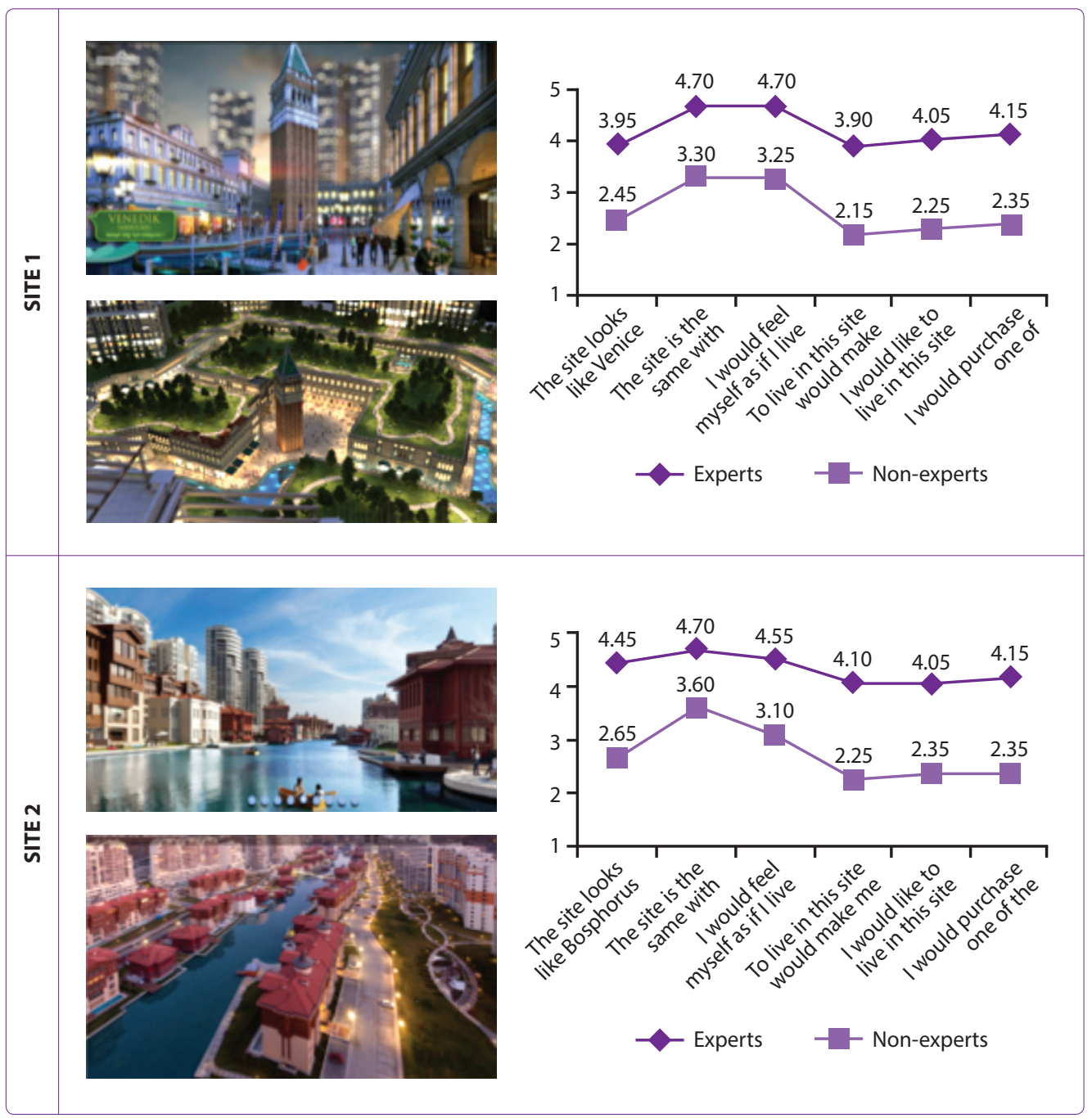

Figure 1. Combined rating profiles showing the attitudes of two groups (architects and non-architects) towards Site1 and Site2 (1: strongly agree; 5: strongly disagree) images: (http://bosphoruscity.com.tr/; http://www.viaportvenezia.com). 
ticipants evaluated the settings in terms of "liked" or "disliked".

\section{Research Findings}

Residents' responses for each site were converted into quantitative and qualitative data; presented through descriptive statistics, combined rating profiles and classification of descriptive words including significant differences and similarities.

\section{Demographic Characteristics}

Demographic characteristics of the respondent group is shown in the Table 2. Questionnaire was applied to experts and non-experts in the field of architecture from Istanbul which are mostly between 20-40 years old age. More than half of the respondent group are female and half of them are married.

\section{Attitudes Toward the Residential Settlements}

The data on respondents' attitudes toward the selected residential environments were collected through a 5-point rating scale and ratings of the participants were superposed graphically (Figure 1). The rating graphics show that there is a significant difference between the attitudes of architects and non-architects towards the two residential settings.

Evaluation of the data gathered from architects indicates that, they have a negative evaluation on the statements that were given for each site. They are

Table 3. Classification of descriptive words

\begin{tabular}{|c|c|c|c|c|}
\hline & Design and context & Function-units & Quality & Location \\
\hline \multirow[t]{8}{*}{ Architects } & Imitation & Water & Like Jail & Far from city center \\
\hline & Artificial & Open spaces & & \\
\hline & Density & Square & & \\
\hline & Visuality & Green spaces & & \\
\hline & Social segregation & Social spaces & & \\
\hline & Relationship with & Lightning & & \\
\hline & Water & High-rise & & \\
\hline & Planned site & buildings & & \\
\hline \multirow[t]{7}{*}{ Non-architects } & Imitation & Water & Active life & Far from city center \\
\hline & Artificial & Square & New & \\
\hline & Planned site & Green spaces & Dreamlike & \\
\hline & Isolated from & Social spaces & Spacious & \\
\hline & environment & Recreation & Open & \\
\hline & Planned site & High-rise buildings & Boring & \\
\hline & Vista & Tower & Inhospitable & \\
\hline \multirow[t]{9}{*}{ Architects } & Imitation & Water & New & Far from city center \\
\hline & Artificial & Waterside houses & Narrowness & \\
\hline & Density & Roofing & Imitated & \\
\hline & Relationship with & High-rise buildings & Bosphorus & \\
\hline & Water & & & \\
\hline & Planned site & & & \\
\hline & Kitsch & & & \\
\hline & Type diversity & & & \\
\hline & Rowing-boat & & & \\
\hline \multirow[t]{7}{*}{ Non-architects } & Artificial & Water & New & Far from city center \\
\hline & Density & Waterside houses & Narrowness & \\
\hline & Planned site & High-rise buildings & Imitated & \\
\hline & Type diversity & Low-rise buildings & Bosphorus & \\
\hline & Rowing-boat & Green spaces & Quietness & \\
\hline & View of Bosphorus & & Beautiful & \\
\hline & & & Modern & \\
\hline
\end{tabular}


mostly disagree with the statements "the site is the same with Venice (mean 4.70) /Bosphorus (mean 4.70)" and "I would feel myself as if I live in Venice (mean 4.70) /Bosphorus (mean 4.55) in this site".

Non-architects mostly had a positive view about each site. They were mostly agree with the statements "To live in this site would make me happy (Site1:mean 2.15/Site2:mean 2.25)", "I would like to live in this site (Site1:mean 2.25/Site2:mean 2.35)", and "I would purchase one of the houses if I could afford (Site1:mean 2.35/Site2:mean 2.35)".

\section{Evaluation of Visual Characteristics}

In this study, open-ended questions were asked to understand "the best-liked" and "the least-liked" features of the residential environments. This technique was used in order to understand how architects and non-architects define the selected settlements, and to discover the cues that affect their evaluations positively or negatively. A similar classification technique was used by Sanoff (1991) to explain the visual characteristics of the physical environment.

The participants used more than 150 descriptive words to explain the selected residential environments.
The words were classified into four major categories according to the responses: "design and context", "function-units", "quality" and "location". The classification of descriptive words is shown in the above table (Table 3). The descriptive words were grouped with respect to their similarities in terms of meaning. The categorization was done by two colleagues, who agreed $90 \%$ with the similarities between the adjectives. For instance, features related with "imitation", "density", and "relationship with the environment" were grouped under "design and context" while features related with "open spaces", "water", and "square" were grouped under "function-units". Features such as "dreamlike", "new", and "boring" were grouped under "quality"; and features such as "far from city center" were grouped under "location".

The positive and negative usages of the words were also important and taken into consideration (Figure 2). In the scope of this research, the evaluation of the subjective data is explained below;

- Features of the each setting related with "design and context" were mostly evaluated negatively (ie:imitation, artificial) by the architects. Inversely, they defined the features related with

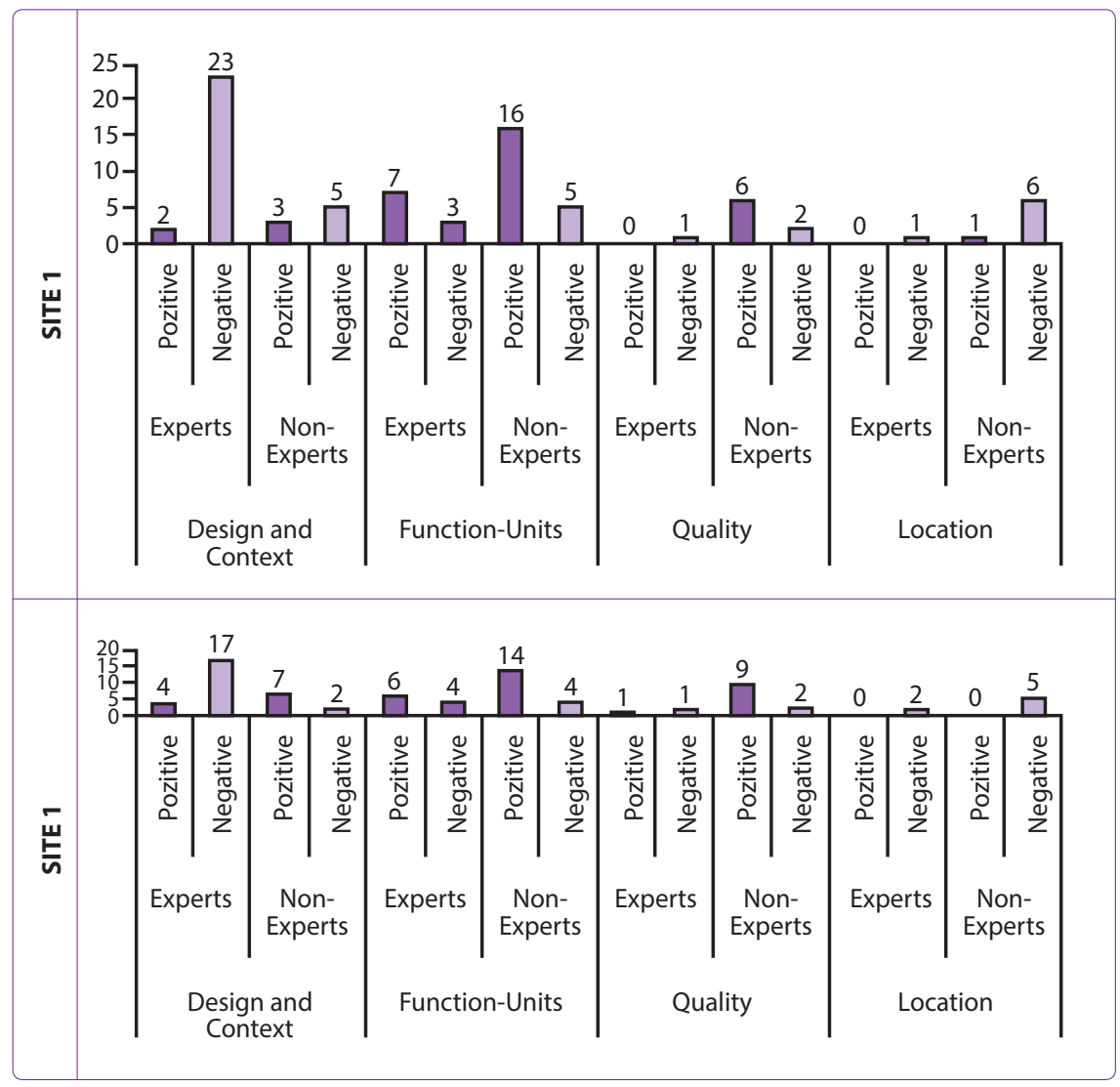

Figure 2. Positive and negative usage of descriptive words for the settings. 
"function-units" (ie: social spaces, recreation) positively for each site.

- Non-architects defined the features related to "function-units" (ie: waterside houses, green spaces) and "quality" (ie: new, dreamlike, strong) positively.

- Architects and non-architects defined the features of the settings related with their locations (far from city center) negatively.

\section{Results and Discussion}

It is a fact that people from different backgrounds differ in the way they perceive and evaluate the environment. Within this study it is explored that architects and non-architects have different viewpoints while they execute their evaluations of the residential environments as potential users.

In this study, open-ended questions helped us to (1) understand which words were mainly used to describe each site and (2) find out what were the cues that affect the participants to choose the sites as "like" or "dislike". The comparison of the data gathered from two different groups, gave us also opportunity to (3) evaluate the attitudes and evaluations of these two groups.

Data gathered from the open-ended questions shows that architects mostly were focused on and concerned with the "design and context" of the sites while non-architects were focused on "fuction-units" and "quality". Architects mostly used the words "imitation, artificial, kitsch" negatively while they were defining the least liked features of each setting. They were mostly disagree with the statements "the site looks like Venice/Bosphorus" and "the site is the same with Venice/Bosphorus".

Non-architects were not interested in "living in Venice" or "being near Bosphorus" concepts, they were mostly impressed by the newness of the sites, social and recreational facilities and being planned and organized sites, features which they are deprived of within the city center.

Pallasma suggests that the excessive flow of imagery gives rise to an experience of a discontinuous and displaced world (Pallasmaa, 2011). Today, it is observed that the approach on generating themes that offer experiences of a fantastic unreal context is applied not only in theme parks or hotel buildings but also in largescale residential projects in Turkey. The residential settlements imitated or were inspired by Ottoman and Turkish vernacular houses; at the present time, certain projects with themes such as "living in Istanbul but in Venice" or "in any part of Istanbul but in Bosphorus" are offered. Similar examples are observed in different parts of the world such as America, Egypt and China, using different themes. On the other hand, in Turkey as well as in other countries round the globe, there is a rise in and growing popularity with respect to privately governed residential, industrial, and commercial spaces. Particularly in big metropolises, as well as in Istanbul, there is a rapidly developing construction process in the form of gated housing settlements and other private constitutions, due to the increasing demand. The fact that similar tendencies become widespread indicates the importance of discussing the issue in the fields of architecture.

\section{References}

Akkaya, D.H., Usman, E.E. (2011) Temali Otel: Yok-Mekanla Var Edilmeye Calisilan 'Kurgu Mekan'. Tasarim+Kuram, volume 7, 11-12.

Aslan, E., Erturk, Z., Hudson, J. (2012) Historical References in Architectural Design, Special Emphasis on Anatolian Vernacular Architecture and Turkish Tourism Architecture, LAP Lambert Academic Publishing, Germany.

Cass, J. (2004) Egypt on Steroids: Luxor Las Vegas and Postmodern Orientalism. In Lasansky, D.M. \& McLaren, B. (Eds.) Architecture and Tourism, Perception, Performance and Place (241-263) Berg, New York, USA.

Castells, M. (2004) The Power of Identity: The Information Age, Economy, Society and Culture. Volume II. WileyBlackwell, UK.

Easterling, K. (2005) Enduring Innocence, Global Architecture and Its Political Masquerades. The MIT Press, Cambridge.

Erdogan, E., Akalın, E., Yıldırım, K., Erdogan, H.A. (2010) Aesthetic Differences Between Freshmen and Pre-architects. Gazi University Journal of Science. 23(4):501-509.

Firat, A.F. \& Ulusoy, E. (2011) Living a Theme. Consumption Markets \& Culture, 14:2, 193-202, DOI: 10.1080/10253866.2011.562020.

Fisher, H. The Image of a Region, The Need for a Clear Focus. In Fladmark, J.M. (Ed.) Cultural Tourism, pp.147-155. The Robert Gordon University, Aberdeen, 1994.

Garip, S.B., Şener, H. Analysing Environmental Satisfaction in Gated Housing Settlements: A Case Study in Istanbul, A I Z ITU Journal of the Faculty of Architecture, p. 120-133, Vol.9, Spring 2012.

Gebauer, G. \& Wulf, C. (1995) Mimesis, Culture, Art, Society. University of California Press, California.

Halliwell, S. (2002) Aesthetics of Mimesis: Ancient Texts and Modern Problems, Princeton University Press, USA.

Hubbard, P. (1996) Conflicting Interpretations of Architecture: An Empirical Investigation, Journal of Environmental Psychology, 16: 75-92.

Melberg, A. (1995) Theories of Mimesis. Cambridge University Press, Cambridge. 
Milman, A. (2010) The Global Theme Park Industry. Worldwide Hospitality and Tourism Themes. Vol. 2 Iss: 3, pp.220-237.

Pallasmaa, J. The Embodied Image, Imagination and Imagery in Architecture. John Wiley \& Sons Ltd., UK., 2011.

Potolsky, M. (2006) Mimesis, New York, London: Routledge.

Ritzer, G. \& Stillman, T. (2001) The Modern Las Vegas CasinoHotel: The Paradigmatic New Means of Consumption, Management, Vol.4, pp.83-99 (http://www.cairn.info/ revue-management-2001-3-page-83.htm).

Sanoff, H. (1977) Methods of Architectural Programming. Dowden, Hutchinson \& Ross, Inc., USA.

Sanoff, H. (1991) Visual Research Methods in Design. Van Nostrand Reinhold, New York, USA.

Sanoff, H. (2006a) Measuring Attributes of the Visual Environment, in 53 Research Papers in Social Architecture (Ed.) H. Sanoff, Aardvark Global Publishing Company, LLC, 229-245.

Sanoff, H. (2006b) Youth's Perception and Categorizations of Residential Cues, in 53 Research Papers in Social Archi- tecture (Ed.) H. Sanoff, Aardvark Global Publishing Company, LLC, 132, 145.

Urry, J. (1999) Mekanlari Tuketmek, Ayrinti Yayinlari, Istanbul.

Venturi, R., Scott Brown,D, Izenour, S. (1977) Learning from Las Vegas: The Forgotten Symbolism Of Architectural Form. Cambridge, Mass.: MIT Press.

Wilson, M.A. (1996) The Socialization of Architectural Preference. Journal of Environmental Psychology. 16:33-44.

\section{Internet References}

Bosphorus City web site. http://bosphoruscity.com.tr/ (Retrieval Date: 01.09.2014)

Rybczynski, W. When Architects Plagiarize. Slate. http:// www.slate.com/articles/arts/architecture/2005/09/ when_architects_plagiarize.html (Retriaval Date: September, 2005).

Viaport Venezia web site. http://www.viaportvenezia.com/ (Retrieval Date: 01.09.2014). 